\title{
Protection of Family Rights of a Person by a Court
}

\section{Alyona Dutko}

Abstract: The paper analyses the forms and methods of protection of family rights and interests. It is noted that judicial protection is the most effective and universal; it guarantees the correct application of the law, the establishment of real rights and responsibilities of individuals. The right of participants in family relations to judicial protection is considered, noted on the procedural features of family cases in civil proceedings in Ukraine. The concepts of "private life" and "family life" in the case law of the European Court of Human Rights are analysed. Particular attention is paid to the protection of children's rights in court, especially in the European Court of Human Rights. The author concludes that there is a need for further comprehensive systematic analysis of the problem of legal regulation of family rights which will provide an opportunity to ensure these rights at the national level, and further guarantee them at the European level.

Key Words: Civil Law; Family Law; Jurisdictional Form of Protection of the Right; Court; Participant in Family Relations; Child; European Court of Human Rights; Ukraine.

\section{Introduction}

The family is a unique social and legal institution, the essence of which is to live together, to give birth and to raise children, to run a joint household, mutual support and assistance, mutual communication, care, etc. Therefore, one of the most important aspects in the science of family law is to ensure proper protection of family rights, the violation of which, in turn, negatively affects the stability of marriage and the relationships of family members.

There are two main forms of protection of family rights: jurisdictional and non-jurisdictional (self-defense).

Jurisdictional form of protection of family rights is the activity of the state-authorized bodies to protect family rights and interests of participants in family relations. Bodies that provide such protection in Ukraine include: courts, guardianship authorities, notaries, prosecutors, etc. 
Within the jurisdictional form of protection, in turn, there are general (judicial) and special (administrative) procedures for the protection of violated family rights.

\section{Right of participants of family relations to judicial protection}

Judicial form of protection is universal, historically formed, regulated in detail by the rules of civil procedural law; this form provides reliable guarantees of the correct application of the law, the establishment of real rights and responsibilities.

Judicial protection of family rights is the most effective, because the court, considering a specific case of family law, primarily guided by applicable law, takes into account all the circumstances of the case and makes decisions based on the interests of minors and incapacitated family members. In civil proceedings, in some cases affecting the rights and interests of minors and incapacitated family members, the prosecutor and guardianship authorities are involved, thus guaranteeing comprehensive state protection of these segments of the population.

The right to protection of family law should be understood as the possibility provided by law to apply to the court or to other competent authorities with a request to take statutory measures of influence aimed at stopping illegal actions, recognizing or restoring the violated family law.

Article 4 of the Civil Procedure Code of Ukraine states that every person has the right in the manner prescribed by this Code to go to court to protect his/her violated, unrecognized or disputed rights, freedoms or legitimate interests.

In accordance with the Part 10 of the Article 7 of the Family Code of Ukraine, each participant in family relations has the right to judicial protection. Every participant in family relations who has reached the age of fourteen years has the right to go directly to the court to protect his or her right or interest (Part 1 of the Article 18 of the Family Code of Ukraine). Parents have the right to apply to the court as legal representatives of the child without special powers (Part 2 of the Article 154 of the Family Code of Ukraine).

In Ukraine, protection of family rights is carried out in civil proceedings in lawsuits, separate and injunctive proceedings. 
In general litigation, courts consider cases arising from family relationships, except for cases which are considered in other proceedings. Certain family law claims are considered in court not because the parties are in a state of conflict, but because the resolution of this issue by law is attributed only to civil jurisdiction, through which the state not only controls the process of changing or terminating family relationships, but also eliminates violation by some subjects of family legal relations of the rights and legitimate interests of other subjects, and also does not allow abuse of rights. In particular, in simplified proceedings may be considered cases of recovery of alimony, divorce, cases of granting the court permission for temporary departure of a child from Ukraine to a parent who lives separately from a child who has no arrears of alimony and who is denied a second from parents in giving notarized consent to such departure.

Requirements for the recovery of alimony are: for one child - one quarter, for two children - one third, for three or more children - half of the earnings (income) of the alimony payer, but not more than ten subsistence minimums for a child of the appropriate age may be considered for each child, if this requirement is not related to the establishment or the challenge of paternity (maternity) and the need to involve other interested persons.

In separate proceedings, cases of adoption, establishment of a regime of separate residence on the application of the spouses, divorce on the application of the spouse who has children, on the granting of the right to marry are considered.

\section{Procedural features of family cases in civil proceedings in Ukraine}

The general claim proceedings in civil proceedings in Ukraine are intended for consideration of cases which due to complexity or other circumstances it is inexpedient to consider in the simplified claim proceedings. Signs of litigation are: the basis is the claim as a substantive claim arising from family relationships; the presence of a dispute over the right; the presence of two parties (plaintiff and defendant) with opposing interests which are endowed by law with certain powers to protect their rights and interests in court; application form - statement of claim; payment of court fees for filing a statement of claim (which is, for example, for filing a statement of claim for divorce -0.4 of the subsistence level for ablebodied persons, for filing a statement of division of property in the case of divorce -1 percent of the claim price, but not less than 0.4 of the sub- 
sistence level for able-bodied persons and not more than 3 subsistence minimums for able-bodied persons); ${ }^{1}$ the possibility of appeal and enforcement of the decision. However, it should be noted that the legislator imposes certain restrictions on filing a lawsuit. In particular, Article 110 of the Family Code of Ukraine states that "a lawsuit for divorce may not be filed during the wife's pregnancy and within one year after the birth of the child, unless one of the spouses has committed illegal conduct that contains signs of a criminal offense, in respect of the other spouse or child." There are exceptions to this rule: 1 ) husband, wife have the right to sue for divorce during the wife's pregnancy, if the paternity of the conceived child is recognized by another person, 2) husband, wife have the right to sue for divorce before the child reaches one year, if paternity in respect of child is recognized by another person or by court decision information about the husband as the child's father is excluded from the birth record of the child.

In many cases, the legislator establishes alternative jurisdiction (jurisdiction of cases of the plaintiff's choice); for example, claims for alimony, increase their size, payment of additional costs for the child, collection of penalties for late payment of alimony, indexation of alimony, change the method of recovery or on the recognition of the paternity of the defendant may be presented at the registered place of residence or stay of the plaintiff or defendant; divorce claims may also be brought at the plaintiff's registered place of residence or stay if he or she has minor child or minor children or if he or she is unable to travel to the defendant's place of residence due to health or other valid reasons; by agreement of the spouses, the case may be heard at the registered place of residence or stay of any of them.

Characteristic features of injunction proceedings in which family cases can be considered are: 1) the absence of a dispute over the right; 2) special subjects: the applicant - the person who has the right of claim and who applies to the court for a court order and the debtor - the person from whom the debt collector requests recovery; 3 ) a special form of a court decision is a court order which is issued on clearly defined grounds by law and which is an executive document; 4) simplified, as there is a "truncated" civil procedural form: - it is not subject to the prin-

1 The subsistence level is a value sufficient to ensure the normal functioning of the human body, to preserve one's health, set of food as well as the minimum set of non-food items and the minimum set of services necessary to meet the basic social and cultural needs of the individual. 
ciples of publicity, oral, immediacy, adversarial proceedings; - no counter-dose can be given; - a reduced model of the stages of the civil process is involved - there is no preliminary hearing, trial on the merits; - a court order is issued in the absence of the parties; 5) shortened terms of issuing a court order are applied - 5 days; 6 ) the court order is revoked by the same court that issued it; 7) the court order is not appealed in the appellate and cassation instances.

Signs of a separate proceeding are: the stated requirements must be indisputable; the purpose of the trial is to establish the presence or absence of the fact; cases of separate proceedings are initiated upon application; the parties to the case are the applicant and the interested persons (the absence of a dispute over the right determines the absence of parties with opposing interests, the absence of a claim); there are no institutions and categories inherent in litigation (filing a counterclaim, replacement of the parties, complicity, amicable agreement, third parties, appeal to the arbitral tribunal, etc.); cases of separate proceedings are considered by the court in compliance with the general rules established by the Civil Procedure Code of Ukraine, except for the provisions on adversarial proceedings and the limits of judicial review; the parties to the case have the right to appeal the court decision; as a general rule, no enforcement proceedings are instituted.

It should be noted that in the period from January to June 2020, the courts of Ukraine considered 1189 cases arising from family relationships. $^{2}$

\section{Ways to protect family rights}

Article 5 of the Civil Procedure Code of Ukraine states that "in the administration of justice, the court protects the rights, freedoms and interests of individuals, the rights and interests of legal entities, state and public interests in the manner prescribed by law or contract. If the law or the contract does not determine an effective way to protect the violated, unrecognized or disputed right, freedom or interest of the person who ap-

2 See Information on the State of Administration of Justice in the Civil Court of Cassation of the Supreme Court in the First Half of 2020 [online]. 2020. 13 p. [cit. 2020-09-15]. Available at: https://supreme.court.gov.ua/userfiles/media/new_folder_for_uploads/supreme/ zvit_KCS_2020.pdf [in the Ukrainian original Інформація про стан здійснення правосуддя у Касаційному цивільному суді у складі Верховного Суду у першому півріччі 2020 року [онлайн]. 2020. 13 с. [цит. 2020-09-15]. Доступно на: https://supreme.court.gov. ua/userfiles/media/new_folder_for_uploads/supreme/zvit_KCS_2020.pdf]. 
pealed to the court, the court, in accordance with the claims of such person, may determine in its decision such a method of protection that does not contradict the law."

According to the legislation of Ukraine, the court applies methods of protection established by law or by agreement of the parties. Their list is given in the Article 18 of the Family Code of Ukraine: ${ }^{3}$

1) establishing a legal relationship (for example, recognition of paternity - Article 128 of the Family Code of Ukraine, maternity - Article 131 of the Family Code of Ukraine, adoption of a child - Article 224 of the Family Code of Ukraine);

2) enforcement of a voluntarily unfulfilled duty (for example, recovery of alimony on the basis of a notary's writ of execution in the case of non-fulfilment of obligations by one of the parents under the alimony agreement - Article 189 of the Family Code of Ukraine);

3) termination of the legal relationship as well as its annulment (for example, divorce - Article 109 of the Family Code of Ukraine, invalidation of marriage - Articles 40 and 41 of the Family Code of Ukraine, deprivation of parental rights - Article 164 of the Family Code of Ukraine, cancellation of adoption - Article 238 of the Family Code of Ukraine);

4) cessation of actions that violate family rights (for example, removal of obstacles in communication with the child by one of the parents, if the parents live separately - Article 159 of the Family Code of Ukraine);

5) restoration of the legal relationship that existed before the violation of the law (for example, restoration of parental rights - Article 169 of the Family Code of Ukraine);

6) compensation for material and moral damage, if it is provided by the Family Code of Ukraine or the contract (for example, compensation for moral damage caused in connection with the violation of the right to maternity, paternity - Articles 49 and 50 of the Family Code of Ukraine);

7) change of legal relationship (establishment of the regime of separate residence of the spouses - Articles 119 and 120 of the Family Code of Ukraine);4

3 See Article 189 of the Family Code of Ukraine of 10 January 2002, No. 2947-III, as amended.

4 See VERBA-SYDOR, O., U. VOROBEL, T. PODOROZHNA, A. DUTKO and N. GRABAR. Models of Legal Regulation of Spousal Separate Residence Regime in the Countries of the European Union and Ukraine. Revista Amazonia Investiga [online]. 2020, vol. 9, n²6, pp. 6-18 
8) recognition of illegal decisions, actions or omissions of a body of state power, a body of power of the Autonomous Republic of Crimea or a body of local self-government, their officials and officials.

This list of ways to protect family rights is not exhaustive, so the court may use other methods (recognition of the right, recovery of penalties, invalidation of the transaction, etc.).

The presence in family law of a wide range of means of protection encourages the parties to the legal relationship to properly exercise their rights and responsibilities.

\section{Concept of "private life" and "family life" in the practice of the European Court of Human Rights}

Article 55 of the Constitution of Ukraine guarantees everyone the right, after using all national remedies, to apply for protection of his/her rights and freedoms to the relevant international judicial institutions or to the relevant bodies of international organizations of which Ukraine is a member or participant. One of the most important international judicial bodies is the European Court of Human Rights, created by the European Convention for the Protection of Human Rights and Fundamental Freedoms (hereinafter referred to as the "Convention").

Guaranteeing the right to respect for family life, Article 8 of the Convention is based on the presumption of the existence of family. This article does not distinguish between different types of family relationships and the "family life" within the legal and extramarital family. The European Court of Human Rights considers that the notion of "family life" is not limited only to marital relations and may extend to actual family relations.

Respect for family life implies the duty of the state to act in such a way as to allow the normal development of family relations, especially of relationships between parents and children. "Respect" is understood not only as a prohibition on the state intervention, but also as imposing on the state a positive obligation to ensure by law and other means respect for the private life of the citizen and its protection from interference by third parties.

[cit. 2020-09-15]. ISSN 2322-6307. Available at: https://doi.org/10.34069/ai/2020.26. 02.1 . 
The concept of "family life" is interpreted very broadly in the case law of the European Court of Human Rights, up to the recognition of the right to family life between the actual father and the child whose mother the father terminated before the child was born. The European Court of Human Rights pointed out that the concept of family life outlined in the Article 8 of the Convention includes the relationship that exists between a person and his/her child, even if the mother and the father do not live together and regardless of whether the child was born in or out of wedlock. The European Court of Human Rights found that the support and encouragement of the traditional family were in themselves legitimate, and even commendable. However, in order to achieve these goals, it is not possible to resort to measures, the purpose or result of which is to harm the "illegal" family; members of the "illegal" family enjoy the guarantees of the above-mentioned Article 8 along with members of the traditional family.

In connection with the above-stated, it is important to note that the European Court of Human Rights has expanded the concept of "family life", in order to take into account modern changes in social and cultural models of family life. Family relations are essentially protected, even if they have no legal form, and formal, legal relations are subject to protection, even if they are devoid of real meaning.

The European Court of Human Rights has repeatedly pointed out in its judgments the inseparability of family ties, and also noted the existence of a positive obligation of the state to reunite parents with their child. In particular, it was emphasized that measures aimed at the permanent removal of parents from contact with their child should be applied only in exceptional circumstances and can be justified only where their use is motivated by the highest interests of children.

The rights guaranteed by paragraph 1 of the Article 8 of the Convention are not absolute. As stated in paragraph 2 of the same Article 8, the right to respect for private and family life, housing and correspondence may be restricted in the interests of national security, public safety or economic well-being, health, morals or to protect the rights and freedoms of third parties, to prevent riots or crimes.

In assessing the interference with the rights guaranteed by the Article 8 of the Convention, the European Court of Human Rights uses the following legal position: interference is permissible and justified if it is aimed at achieving a legitimate aim and is provided for by domestic law. 
At the same time, the law should contain clear and unambiguous corresponding provisions, it should provide effective means of protection, and the citizens should be able to get acquainted with such a law. Permissible interference in accordance with the law must satisfy the criterion of proportionality. It is important that in each case the intervention be a balance between the rights of the individual and the protected interests of the society as a whole.

\section{Protection of the rights of a child in court}

A child is a separate subject of family legal relations whose rights require special protection. For a long time, the rights of a child were not affected at the international level. The Universal Declaration of Human Rights only stated quite generally that the enjoyment of rights does not depend on age and emphasized the need to protect children. It was not until year 1989 that the Convention on the Rights of the Child was adopted, which treats children as subjects of civil and political rights. The Convention on the Rights of the Child lists the basic rights of the child: the right to register, the right to a name, the right to preserve one's identity and the prohibition of interference in this field, and so on. The European Convention for the Protection of Human Rights and Fundamental Freedoms draws attention to the fact that children as weak and vulnerable subjects need special protection, and there can be no question of age discrimination.

The case law of the European Court of Human Rights in the field of protection of the rights of a child should be considered in the light of the principles of the legal status of a child. There are principles of the legal status of a child which follow from international legal instruments, first of all, from the Convention on the Rights of the Child of 1989, and which are: equality of children (Article 2); inadmissibility of any forms of discrimination (Article 2); priority of the interests of the child in resolving any issue concerning children, the so-called principle of the best interests of the child (Article 3); the principle of protection and care for the welfare of the child (Article 5); inalienability and priority of the right to life (states have duty to ensure survival and development of children, Article 6); the child's right to express his/her opinion, to present information about his/her problems (children have the right to be heard, Articles 12 15); the principle of preserving the individuality of the child (Article 8); the principle of parental responsibility for the upbringing and development of the child (Article 18). 
To this date, numerous the European Court of Human Rights decisions on issues related to the protection of children's rights are based on the provisions of the European Convention for the Protection of Human Rights and Fundamental Freedoms, the Universal Declaration of Human Rights and the provisions of the Convention on the Rights of the Child.

Traditionally, the European Court of Human Rights pays great attention to matters related to determining the child's place of residence as well as the exercise of the right to communicate with his/her not only parents but also other relatives, such as grandparents. Principle 6 of the Declaration of the Rights of the Child, proclaimed by the United Nations General Assembly Resolution of 20 November 1959, states that a child needs love and understanding for the full and harmonious development of his or her personality. He or she should, if possible, grow up under the care and responsibility of his/her parents and in any case in an atmosphere of love and moral and material security; a minor child should not be separated from his or her mother, unless there are exceptional circumstances.

Judges of the Grand Chamber of the Supreme Court of Ukraine consider that in determining a child's place of residence, priority is given to the best possible interests of the child, taking into account the requirements of the Article 3 of the Convention on the Rights of the Child of 20 November 1989. As for the Declaration of the Rights of the Child, the Grand Chamber of the Supreme Court of Ukraine notes that the Declaration of the Rights of the Child is not an international treaty approved by the Verkhovna Rada of Ukraine and is not part of the national legislation of Ukraine. And the legislation of Ukraine does not contain norms that would give any of the parents a priority right to live with the child.

When considering cases concerning a child's place of residence, the courts in Ukraine must first and foremost take into account the interests of the child himself/herself, taking into account stable social ties, place of study, psychological conditions, and so on. ${ }^{5}$ This decision was preceded by a case before the European Court of Human Rights.

5 See The Grand Chamber of the Supreme Court Changed the Case Law in Disputes over the Determination of the Child's Place of Residence [online]. 2018-11-07 [cit. 2020-09-15]. Available at: https://supreme.court.gov.ua/supreme/pres-centr/news/592663/ [in the Ukrainian original Велика Палата ВС змінила судову практику у спорах про визначення місия проживання дитини [онлайн]. 2018-11-07 [цит. 2020-09-15]. Доступно на: https://supreme.court.gov.ua/supreme/pres-centr/news/592663/]. 
On 11 July 2017, the European Court of Human Rights ruled in the case "M.S. v. Ukraine", ${ }^{6}$ which found a violation of the Article 8 of the Convention by Ukraine.

In our opinion, the importance of this decision is that it addresses topical issues related to the protection of family rights, especially the rights of the child which are quite common in the Ukrainian realities.

Thus, briefly mentioning the circumstances of the case, it should be emphasized that it concerned the applicant who was in a relationship with a woman with whom he later married and they had a joint child (daughter). From the time the child was born, the couple and their daughter lived in the applicant's apartment, where the applicant's parents also helped to raise the child. The applicant and his wife had been working abroad for some time, so the applicant's parents were worried about the child during their absence.

Over time, the relationship between the applicant and his wife deteriorated and the wife took the child without the applicant's consent and moved to another place, namely a village near the town where they lived, where she probably lived with her uncle. The applicant later found the child's whereabouts and took her to his home, as there were suspicions of violence and sexual abuse caused by the wife and her roommate.

Regarding these facts, he repeatedly appealed to the law enforcement agencies which for a long time, even before the case was brought before the European Court of Human Rights, conducted investigations, then closed the case, and then revoked the decisions to close the case.

After the applicant's return to the city, the child lived with him and his parents and the wife could communicate with the child only in the presence of the applicant or other persons.

The decision of the district court with the reference to the United Nations Declaration of the Rights of the Child of 1959, the Convention on the Rights of the Child of 1989 and the Article 161 of the Family Code of Ukraine stipulated to determine the place of residence of the child with his/her mother.

The European Court of Human Rights found a violation of the Article 8 of the Convention which guarantees the right to respect for private

6 See Case of M.S. v. Ukraine [2017-07-11]. Judgement of the European Court of Human Rights, 2017, Application No. 2091/13. 
and family life and covers both the criminal sphere (proper investigation into the use of violence against a child) and the civil sphere for determining the child's place of residence.

The European Court of Human Rights considered that the analysis carried out by the domestic courts prior to the decision that the applicant's daughter was to live with her mother was insufficiently substantiated. Therefore, despite the wide discretion granted to national authorities in the field of child's custody, the reasons they give for addressing them cannot be considered "appropriate and sufficient". Accordingly, there has been a violation of the Article 8 of the Convention concerning the determination of the applicant's child's place of residence (paragraphs 85 - 86).

Thus, in assessing the proportionality of the interference, the European Court of Human Rights reiterated its general principle that two conditions must be taken into account in determining the best interests of the child in each case: firstly, the best interests of the child will be maintained, except when the family is particularly unfit or clearly unhappy; secondly, it is in the best interests of the child to ensure that he or she develops in a safe, calm and stable environment that is not unfavourable (paragraph 76).

It is interesting to note that prior to the conflict between the parents, the child had always lived in the applicant's apartment, where she had a stable environment. The child's further relocation disrupted the stability of the child's daily life: she had to live in a new house in another residential area and she had to visit a new institution and communicate with new people around her. At the time of the civil dispute, the mother moved again, where she lived in another apartment, which was again a new environment that the child had to accept. Importantly, the European Court of Human Rights noted that the judgments did not show that any of these issues had been duly considered (paragraph 83).

So, summing up, we conclude that this decision confirmed the stable position of the European Court of Human Rights, which is to determine primarily the "best interests of the child" and not the parents, which requires a detailed study of the situation, taking into account various factors that may affect the interests of the child and procedures in resolving the dispute for all parties.

Of course, the judgment of the European Court of Human Rights should not be an example of the unconditional obligation of national 
courts to decide matters in favour of the father. It requires an approach to determine the proportionality of interference with the rights and in this aspect of the interests of the child and, depending on the specific circumstances of the case, to resolve the issue in favour of the "interests of the child."7

Finally, we can add that some case law decisions of the European Court of Human Rights concern the establishment of paternity and the protection of the interests of illegitimate children. For example, in the case "Kalacheva v. Russia" from 7 May 2009,8 the applicant appealed against the refusal of the Russian courts to establish the origin of her illegitimate child from her biological father on the basis of a DNA examination. The European Court of Human Rights stated that DNA analysis is currently the only scientific method of accurately establishing the paternity of a particular child and its probative value significantly exceeds any other evidence presented by the parties to confirm or to refute their close relationship.

\section{Conclusions}

Thus, at the present stage of development of the legal science we can talk about the need for new comprehensive research on the protection of family rights. Nowadays, family rights also require scientific understanding and comprehensive systematic analysis of the problem of legal regulation of the exercise and the protection of children's rights which will provide an opportunity to ensure these rights at the national level, and further guarantee them at the European level. The current Ukrainian family legislation does not solve all the practical problems in the field of protecting family rights. Historically, in Ukraine, family law has been separated from civil law; therefore, individual family legal methods of protection are repeated in terms of the content and the procedure for their application. However, the corresponding civil legal methods of protection

\footnotetext{
7 See PARKHOMENKO, P. The Significance of the Decision of the ECtHR in the Case "M.S. against Ukraine" for Law Enforcement Practice. In: Jurliga [online]. 2017-07-25 [cit. 2020-09-15]. Available at: https://jurliga.ligazakon.net/analitycs/162658_znachennyarshennya-spl-u-sprav-ms-proti-ukrani-dlya-pravozastosovcho-praktiki [in the Ukrainian original ПАРХОМЕНКО, П. Значення рішення ЄСПЛ у справі «М.С. проти України» для правозастосовчої практики. В: Юрліга [онлайн]. 2017-07-25 [цит. 2020-09-15]. Доступно на: https://jurliga.ligazakon.net/analitycs/162658_znachennya-rshennya-spl-usprav-ms-proti-ukrani-dlya-pravozastosovcho-praktiki].

8 See Case of Kalacheva v. Russia [2009-05-07]. Judgement of the European Court of Human Rights, 2009, Application No. 3451/05.
} 
or the direct application of the provisions of the Civil Code of Ukraine, providing for the protection of civil rights, it is impossible to use as methods of protecting the family rights due to meaningful features of the family legal relations, which are characterized by the absence of retribution, a special subject composition, duration in time, the presence of close family ties and personal trust. It is necessary to look for new, out-of-court ways to protect the family rights in Ukraine, for example, use of mediation.

\section{References}

Case of Kalacheva v. Russia [2009-05-07]. Judgement of the European Court of Human Rights, 2009, Application No. 3451/05.

Case of M.S. v. Ukraine [2017-07-11]. Judgement of the European Court of Human Rights, 2017, Application No. 2091/13.

Civil Code of Ukraine of 16 January 2003, No. 435-IV, as amended.

Civil Procedure Code of Ukraine of 18 March 2004, No. 1618-IV, as amended.

Constitution of Ukraine of 28 June 1996, No. 254k/96-BP, as amended.

Convention on the Rights of the Child [1989-11-20].

Declaration of the Rights of the Child [1959-11-20].

European Convention for the Protection of Human Rights and Fundamental Freedoms [1950-11-04].

Family Code of Ukraine of 10 January 2002, No. 2947-III, as amended.

Information on the State of Administration of Justice in the Civil Court of Cassation of the Supreme Court in the First Half of 2020 [online]. 2020. 13 p. [cit. 2020-09-15]. Available at: https://supreme.court.gov.ua/ userfiles/media/new_folder_for_uploads/supreme/zvit_KCS_2020. pdf [in the Ukrainian original Інформація про стан здійснення правосуддя у Касаційному цивільному суді у складі Верховного Суду у першому півріччі 2020 року [онлайн]. 2020. 13 с. [цит. 2020-0915]. Доступно на: https://supreme.court.gov.ua/userfiles/media/ new_folder_for_uploads/supreme/zvit_KCS_2020.pdf].

PARKHOMENKO, P. The Significance of the Decision of the ECtHR in the Case "M.S. against Ukraine" for Law Enforcement Practice. In: Jurliga [online]. 2017-07-25 [cit. 2020-09-15]. Available at: https://jurliga. 
ligazakon.net/analitycs/162658_znachennya-rshennya-spl-u-spravms-proti-ukrani-dlya-pravozastosovcho-praktiki [in the Ukrainian original ПАРХОМЕНКО, П. Значення рішення ЄСПЛ у справі «М.С. проти України» для правозастосовчої практики. В: Юрліга [онлайн]. 2017-07-25 [цит. 2020-09-15]. Доступно на: https://jurliga. ligazakon.net/analitycs/162658_znachennya-rshennya-spl-u-spravms-proti-ukrani-dlya-pravozastosovcho-praktiki].

The Grand Chamber of the Supreme Court Changed the Case Law in Disputes over the Determination of the Child's Place of Residence [online]. 2018-11-07 [cit. 2020-09-15]. Available at: https://supreme.court. gov.ua/supreme/pres-centr/news/592663/ [in the Ukrainian original Велика Палата ВС змінила судову практику у спорах про визначення місия проживання дитини [онлайн]. 2018-11-07 [цит. 2020-09-15]. Доступно на: https://supreme.court.gov.ua/supreme/ pres-centr/news/592663/].

Universal Declaration of Human Rights [1948-12-10].

VERBA-SYDOR, O., U. VOROBEL, T. PODOROZHNA, A. DUTKO and N. GRABAR. Models of Legal Regulation of Spousal Separate Residence Regime in the Countries of the European Union and Ukraine. Revista Amazonia Investiga [online]. 2020, vol. 9, $\mathrm{n}^{\circ} 26$, pp. 6-18 [cit. 202009-15]. ISSN 2322-6307. Available at: https://doi.org/10.34069/ai/ 2020.26.02.1.

Assoc. Prof. Alyona Dutko, Ph.D.

Faculty of Law Lviv State University of Internal Affairs Horodotska St. 26 79007 Lviv Ukraine dutkoalona@gmail.com Dttps://orcid.org/0000-0001-5622-1046 